\title{
Urinary proteoglycan degradation product excretion in patients with rheumatoid arthritis and osteoarthritis
}

\author{
J KRAJÍČKOVÁ AND J MACEK
}

From the Research Institute of Rheumatic Diseases, Praha, Czechoslovakia

SUMMARY The excretion of sugar components of glycosaminoglycans in the urine was investigated in 19 healthy controls, 27 patients with rheumatoid arthritis, and 24 with osteoarthritis. Both groups of patients excreted significantly more glucosamine, galactosamine, and mannose than the controls. The total uronic acid excretion, also, was higher in the two groups than in the healthy subjects. The possibility of using this method for the long term follow up of rheumatoid arthritis and osteoarthritis and the response to treatment is discussed.

Attempts to find a suitable method for qualitative and quantitative determination of connective tissue metabolites in blood and urine as an aid in diagnosis (e.g., cases of inborn errors of glycosaminoglycan metabolism) are not new. Clinical chemistry continues to seek more sensitive and more specific indicators of pathological processes affecting the articular connective tissue. Rheumatic diseases are characterised by cartilage degradation caused by enzymes produced either by the infiltrating cell, granulation tissue, or chondrocytes directly in the cartilage. ${ }^{1-3}$

Composition of the articular cartilage connective tissue is the result of a balance between the continual synthesis and degradation of proteoglycans, collagen, and other components. Degradation products of these molecules appear firstly in the blood and later in the urine. ${ }^{4}$ To obtain information on degradative processes affecting proteoglycans we analysed the sugar components of the glycosaminoglycans and small oligosaccharide chains appearing in the urine.

\section{Patients and methods}

Twenty four hour urine specimens were collected from 19 normal controls (10 women, nine men; average age 48 years), 27 patients with rheumatoid arthritis (stage II-IV according to the Steinbrocker classification; 17 women, 10 men; average age 51

Accepted for publication 14 November 1987.

Correspondence to Dr J Krajíčková, Research Institute of Rheumatic Diseases, 12850 Praha 2, Czechoslovakia. years), and 24 patients with osteoarthritis (12 patients in stages I and II and 12 patients in stages III and IV according to Kellgren; 16 women, eight men; average age 58 years). The renal function was normal in all probands.

\section{ISOLATION OF THE MACROMOLECULAR F R A C T IO N 5}

During the collection time ( 24 hours) urine was kept at $4^{\circ} \mathrm{C}$ in sterile containers without addition of preservatives. The urine volume (between 1000 and $1400 \mathrm{ml}) . \mathrm{pH}$, and specific gravity were recorded. An aliquot was assayed for creatinine and fragments with molecular weight of more than 4000 were isolated by permeation chromatography on Bio-Gel P4. The preparative gel filtration was performed using a modification of the technique of Hurst et al. ${ }^{4}$ After centrifugation a $25 \mathrm{ml}$ sample of filtered urine was applied to a column of Pharmacia Fine Chemicals (K 26/40) packed with Bio-Gel P4 (100-200 $\mu \mathrm{m}$ mesh) to a bed volume of $159.3 \mathrm{ml}$. The sample was eluted with deionised water. The first $65 \mathrm{ml}$ of eluate was discarded and the next $80 \mathrm{ml}$ retained as the macromolecular fraction. The column was then washed with five bed volumes of water. After every fifth sample the column was regenerated by a solution of $2 \mathrm{M}$ urea in $1 \mathrm{M} \mathrm{NaCl}$ followed by 10 bed volumes of buffer.

ISOLATION OF GLYCOSAMINOGLYCANS FROM THE MACROMOLECULAR FRACTION 8 To one part of the urine macromolecular fraction (pH 5) we added a 5\% (w/v) solution of cetyltrimethylammonium bromide. To achieve complete 
precipitation of glycosaminoglycans the solution was left overnight at $4^{\circ} \mathrm{C}$. The precipitate was then separated by centrifugation ( 20 minutes $12000 \mathrm{~g}$ ), washed three times with $\mathrm{NaCl}$ saturated $95 \%$ ethanol, and, after drying in a stream of $\mathrm{N}_{2}$, dissolved in $0.05 \mathrm{M} \mathrm{NaOH}$. Aliquots were then used to determine the content of uronic acids, ${ }^{9}$ individual sugars, and amino sugars ${ }^{10}$

\section{GAS CHROMATOGRAPHY}

Samples were prepared by hydrolysis of neutral sugars and amino sugars catalysed by Dowex $50 \mathrm{~W}$ $\mathrm{X}^{2}\left(\mathrm{H}^{+}\right)$200-400 $\mu \mathrm{m}$ mesh, ${ }^{10}$ with myoinositol as the internal standard. After hydrolysis the hexosamines were deaminated by addition of $5.5 \mathrm{M}$ sodium nitrite to the corresponding neutral 2,5anhydrohexoses. The 2,5-anhydrohexoses were then transformed into neutral alditol acetates by reduction with $0.22 \mathrm{M}$ sodium borohydride and subsequent acetylation with a mixture of pyridine and acetanhydride (1:1). One microlitre of the sample was injected into the gas chromatograph.

Gas chromatography was carried out on a Perkin-
Elmer (Norwalk, Conn, USA) Sigma 2 gas chromatograph equipped with a flame ionisation detector. We used a fused silica capillary column (30 $\mathrm{m} \times 0.26 \mathrm{~mm}$ internal diameter) with chemically stationary phase DB 225 (J and W Scientific, CA, USA; film thickness $0.25 \mu \mathrm{m})$.

The temperatures were as follows: column $215^{\circ} \mathrm{C}$, injector $220^{\circ} \mathrm{C}$, detector $220^{\circ} \mathrm{C}$. The carrier gas was hydrogen with linear flow $75 \mathrm{~cm} / \mathrm{s}$. As make-up gas we used nitrogen with flow $40 \mathrm{ml} / \mathrm{min}$. The split ratio was $1: 20$.

Analysis time was 11 minutes. The peak areas for compounds of interest were measured and compared with those of an internal standard. The results were expressed as milligrams of the respective sugar per 24 hour volume of urine.

\section{Results}

Significant differences between the groups of patients and the control group were observed, mainly in the glucosamine and galactosamine content (Table 1). Both of these amino sugars were

Table 1 Sugar content in urine fraction of $\mathrm{Mr}>4000^{*}$

\begin{tabular}{|c|c|c|c|c|c|c|c|c|}
\hline \multirow[t]{2}{*}{ Sugar } & \multicolumn{2}{|c|}{$\begin{array}{l}\text { Controls } \\
(n=19)\end{array}$} & \multicolumn{3}{|c|}{$\begin{array}{l}\text { Rheumatoid arthritis } \\
(n=27)\end{array}$} & \multicolumn{3}{|c|}{$\begin{array}{l}\text { Osteoarthritis } \\
(n=24)\end{array}$} \\
\hline & Mean & $S D$ & Mean & $S D$ & $p$ Value & Mean & $S D$ & p Value \\
\hline Fucose & $0 \cdot 88$ & 0.52 & 3.98 & $3 \cdot 48$ & 0.001 & 2.97 & $2 \cdot 34$ & NS \\
\hline Glucosamine & $2 \cdot 38$ & $1 \cdot 32$ & $5 \cdot 74$ & $4 \cdot 47$ & 0.005 & $6 \cdot 86$ & $3 \cdot 53$ & $0 \cdot 001$ \\
\hline Xylose & $5 \cdot 58$ & $3 \cdot 24$ & $5 \cdot 33$ & $4 \cdot 40$ & NS & $2 \cdot 55$ & $2 \cdot 72$ & NS \\
\hline Galactosamine & $2 \cdot 10$ & $1 \cdot 25$ & $7 \cdot 46$ & $6 \cdot 19$ & $0 \cdot 001$ & $6 \cdot 80$ & 4.98 & $0 \cdot 001$ \\
\hline Mannose & $2 \cdot 44$ & $1 \cdot 15$ & $4 \cdot 00$ & $3 \cdot 08$ & 0.05 & $6 \cdot 19$ & $4 \cdot 54$ & 0.005 \\
\hline Galactose & $2 \cdot 71$ & $1 \cdot 56$ & $3 \cdot 65$ & $3 \cdot 01$ & NS & $4 \cdot 49$ & $3 \cdot 29$ & NS \\
\hline Glucose & $5 \cdot 76$ & $3 \cdot 14$ & $4 \cdot 62$ & $3 \cdot 26$ & NS & $5 \cdot 38$ & $6 \cdot 22$ & NS \\
\hline
\end{tabular}

*Values are mean, SD $\mathrm{mg}$ in 24 hour urine.

Individual groups of patients were compared by means of Student's $t$ test.

Table 2 Sugar content in urine of the osteoarthritic patients (fraction of $\mathrm{Mr}>4000$ )*

\begin{tabular}{|c|c|c|c|c|c|c|c|}
\hline \multirow[t]{3}{*}{ Sugar } & \multicolumn{3}{|c|}{$\begin{array}{l}\text { Mild form } \\
(n=I 2)\end{array}$} & \multicolumn{3}{|c|}{$\begin{array}{l}\text { Advanced form } \\
(n=12)\end{array}$} & \multirow{3}{*}{$\begin{array}{l}\text { Mild } \\
\times \\
\text { advanced form } \\
p \text { Value }\end{array}$} \\
\hline & \multirow[t]{2}{*}{ Mean } & \multirow[t]{2}{*}{$S D$} & \multirow[t]{2}{*}{ p Value } & \multirow[t]{2}{*}{ Mean } & \multirow[t]{2}{*}{$S D$} & \multirow{2}{*}{ p Value } & \\
\hline & & & & & & & \\
\hline Fucose & $1 \cdot 86$ & $1 \cdot 66$ & NS & $4 \cdot 08$ & $3 \cdot 02$ & $0 \cdot 01$ & 0.05 \\
\hline Glucosamine & $6 \cdot 12$ & $3 \cdot 16$ & - & $7 \cdot 60$ & 3.90 & - & NS \\
\hline Xylose & $1 \cdot 03$ & $1 \cdot 20$ & 0.05 & $4 \cdot 06$ & $4 \cdot 23$ & NS & $0 \cdot 05$ \\
\hline Galactosamine & $6 \cdot 12$ & $5 \cdot 11$ & - & $7 \cdot 48$ & $4 \cdot 84$ & - & NS \\
\hline Mannose & $4 \cdot 53$ & $2 \cdot 83$ & - & $7 \cdot 84$ & $6 \cdot 24$ & - & NS \\
\hline Galactose & $4 \cdot 62$ & $3 \cdot 34$ & - & $4 \cdot 36$ & $3 \cdot 23$ & - & NS \\
\hline Glucose & $3 \cdot 21$ & $2 \cdot 34$ & - & $7 \cdot 54$ & $10 \cdot 1$ & - & NS \\
\hline
\end{tabular}

*Values are mean, SD $\mathrm{mg}$ in 24 hour urine.

Individual groups of patients were compared by means of Student's $t$ test. 
present in higher levels in the urine of patients with rheumatoid arthritis and osteoarthritis. There was also some difference in the mannose content. Table 1 shows the mean values, standard deviations, and significance levels of differences between the controls and groups of patients.

The group of osteoarthritic patients was not homogeneous. For this reason it was divided into two subgroups according to $x$ ray findings: $(a)$ mild (stages I and II) and (b) advanced (stages III and IV). The differences between these subgroups were not substantial, significant differences occurring mainly in the fucose and xylose content belonging to the oligosaccharide chains (Table 2). In rheumatoid patients no relation could be found between stage of the disease (Steinbrocker), disease activity, and the level of excretion of proteoglycan degradation products.

Excretion of uronic acids in healthy subjects was lower than in the patients: the average content of uronic acids in 24 hour urine was $5.0 \mathrm{mg}$ in the control group, $7.9 \mathrm{mg}$ in the group of patients with rheumatoid arthritis, and $6.1 \mathrm{mg}$ in the group with osteoarthritis.

\section{Discussion}

The extracellular matrix of connective tissue consists to a large extent of glycosaminoglycans in the form of proteoglycans, which are covalently bound to a central core protein. Recently, two further components of proteoglycans have been described. Of these small oligosaccharide chains, ${ }^{11} 12$ one type is bound to the core protein by an $O$-glycoside bond containing galactosamine, galactose, glucosamine, and sialic acid. The second type has a higher molecular weight, contains mainly mannose and also glucosamine, galactose, sialic acid, and fucose, and is bound by an $\mathrm{N}$-glycoside bond to the core protein, almost exclusively in its terminal globular part, which contains the hyaluronic acid binding region.

Structural changes brought about in cartilage by both inflammatory and degenerative pathological processes can generally be regarded as degradation of macromolecules of the connective tissue. Primary enzymatic degradation affects the core protein (mainly its globular part) and glycosaminoglycan chains of proteoglycan molecules. The products of their degradation enter the blood circulation and are subsequently excreted in the urine. Determination of these products, especially in the phase of active and generalised destructive processes in the cartilage, can be used as an indicator of the activity of pathological processes taking place in the cartilage.

Biochemical analysis of cartilage in advanced stages of osteoarthritis has shown changes in the structure of proteoglycans. ${ }^{13}{ }^{14}$ Molecules of proteoglycans of lower molecular weight with shortened lateral chondroitin sulphate chains were found. These molecules can be extracted from the cartilage more easily and have a lower aggregating capacity. This may point indirectly to proteolytic splitting of the whole core protein of the proteoglycan as well as the globular part containing the bound oligosaccharide chains.

One of the enzymes active in this respect may be neutral proteinase, which has increased activity in the osteoarthritic cartilage. Furthermore, the glycosidases may degrade the lateral sugar chains of the proteoglycan. $^{2}$ i5 This could explain the increased amount of both galactosamine and xylose (products of degradation of chondroitin sulphate chains from one part of the core protein), as well as mannose, glucosamine, and fucose, which are contained in the oligosaccharide bound in the globular part of the core protein (molecular weight above 4000).

Similar degradative processes have been described in the cartilage of patients with rheumatoid arthritis. Splitting of proteoglycans by degrading enzymes is followed by extensive splitting of collagen molecules. Our results show that patients with rheumatoid arthritis excreted more galactosamine than patients with osteoarthritis, which may point to a more pronounced degradation of chondroitin sulphate chains. Measurement of sugar content in urine provides indirect information about the activity of proteoglycan metabolism. Our preliminary results show that in cases of cartilage destruction, such as in rheumatoid arthritis and to a certain extent also in osteoarthritis, there is increased excretion of sugars in urine. Although proteoglycans are widely distributed in the body, it is probable that changes in cartilage metabolism, especially. contribute to the excretion of these sugars.

Determination of proteoglycan sugars in urine may provide a laboratory marker of connective tissue metabolism and may help in following up the long term course of rheumatoid arthritis and osteoarthritis, and the response to treatment.

\section{References}

1 Ali Y. Evans L. Enzymic degradation of cartilage in osteoarthritis. Fed Proc 1973: 32: 1485-8.

2 Pearson J P. Proteoglycan biochemistry in connective tissuc discase. In: Carson Dick W. Moll J M H, eds. Recent advances of in rheumatology. Edinburgh. London. Melbourne, and New York: Churchill Livingstonc. 1983: 49-72.

3 Peeters-Joris C. Emonds-Alt X. Vaes G. A direct simultaneous place assay of proteoglycans and collagen degradation by cells in culture and its application to synovial cells. Biochem J 1981: 196: 95-103.

4 Hurst R E. Settine J M. Lorincz A E. A method for the quantitative determination of urinary glycosaminoglycans. Clin Chim Acta 1976; 70: 427-33.

5 Calatroni A. Products of the breakdown of glycosaminoglycans 
in normal and pathological human plasma and urine. Ital $J$ Biochem 1974: 23: 267-8.

6 Thorne I D. Resnick M I. A methodology for the characterization of urinary glycosaminoglycans. $J$ Urol 1984; 131: 995-9.

7 Di Ferrante N M. Rich C. The determination of acid aminopolysaccharide in urine. J Lab Clin Med 1956; 48: 491-5.

8 Teller W M, Müller S. Age-dependent changes of glycosaminoglycans precipitable from human urine at acid and alkaline pH. Klin Wochenschr 1974; 52: 1165-72.

9 Blumenkrantz N, Asboe-Hansen G. New method for quantitative determination of uronic acids. Anal Biochem 1973; 54: 484-9.

10 Porter W H. Application of nitrous acid deamination of hexosamines to the simultaneous GLC determination of neutral and amino sugars in glycoproteins. Anal Biochem 1975; 63: $27-43$.
11 Nilsson B. De Luca S, Lohmander S. Hascall V C. Structure of $\mathrm{N}$-linked and O-linked oligosaccharides on proteoglycan monomer isolated from the swarm rat chondrosarcome. J Biol Chem 1982: 257: 10920-7.

12 Santer V, White R J. Roughley P J. O-linked oligosaccharides of human articular cartilage proteoglycan. Biochem Biophys Acta 1982: 716: 277-82.

13 Palmoski M. Brandt K. Hyaluronate binding by protcoglycans: comparison of mildly and severely ostoarthritic regions of human femoral cartilage. Clin Chim Acta 1976: 70: 87-93.

14 Vasan N. Proteoglycans in normal and severely ostcoarthritic human cartilage. Biochem J 1980; 187: 781-7.

15 Sapolsky A I. Keiser H. Howell D S. et al. Metalloproteases of human articular cartilage that digest cartilage proteoglycan at neutral and acid pH. J Clin Invest 1976; 58: 1030-41. 